\title{
Chemical composition of the washing water solution after washing the wheelsets of railway transport
}

\author{
(C) Alexander N. Bezzubov, and Olga A. Golovanova* ${ }^{+}$ \\ Department of Inorganic Chemistry. Chemical Faculty. F.M. Dostoevsky Omsk State University. \\ Mir Ave., 55a. Omsk, 644077. Omsk Region. Russia. \\ Phone:+7 (3812) 64-24-10.E-mail: FKH@omsu.ru
}

\begin{abstract}
*Supervising author; ${ }^{+}$Corresponding author Keywords: washing solution, wheel pairs washing, water treatment, electrolysis, water consumption.
\end{abstract}

\begin{abstract}
The article discusses the impact of economic and industrial water consumption on the state of the hydrosphere and biosphere of the Earth, and also presents the water consumption in Russia, the share of the country's water resources consumed per year and the forecast of water consumption at the end of 2020. The classification of modern methods of wastewater treatment, including in railway depots, is considered. The water consumption and the proportion of circulating water at railway enterprises are analyzed in detail, as well as the most used methods of purification of the used detergent solution (DS) in the enterprise are presented. The description of the work presents the key characteristics of the DS after washing the wheelsets of railway transport, such as $\mathrm{pH}$, total hardness, density and permanganate oxidizability. The data obtained were compared with the requirements (2.1.4.1074-01) and concluded that the water was unsuitable for further operation due to a significant excess of the norm for permanganate oxidizability. The effect of long-term sedimentation of the studied DS was investigated, after which DS was successfully separated into an aqueous phase, an organic phase, a black amorphous organic precipitate, and a yellow amorphous precipitate. The influence of a direct electric current, conducted through the solution at room temperature on carbon electrodes, was studied for a time of 30 minutes, one and three hours. The influence of changes in the $\mathrm{pH}$ of the DS medium with subsequent settling was studied. The results of chemical purification of the water under study with such coagulants as ammonium polymolybdate and bismuth(III) salts, the latter of which made it possible to precipitate phosphate ions from solution, are presented. A qualitative reaction with the use of ammonium thiocyanate proved the content of iron(III) ions in the test solution.
\end{abstract}

\section{References}

[1] M.I. Lvovich. Water and life. Moscow: Thought. 1986. 254p. (russian)

[2] S.Y. Dinstein. Circulation of chemicals in the environment and the health of the population. Moscow. 1977. 72p. (russian)

[3] M.M. Semenova, A.V. Karpov. Methods of cleaning the wheel Pair of rolling stock. Young scientist. 2017. No.10(144). P.92-94. (russian)

[4] CV-944. Date of introduction 2006-01-01 (with changes). Approved by the Ministry of internal Affairs of Russia on June 20, 2003. (russian)

[5] V.I. Danilov-Danilyan, K.S. Losev. Water Consumption: ecological, economic, social and political aspects of water problems Institute of the Russian Academy of Sciences. Moscow: Science. 2006. 221p. ISBN 5-02-033985-7 (TRANS.). (russian)

[6] Y.B. Oliynyk, P.G. Shyshchenko, P.O. Gavrilenko. Principles Ecolog: pidruchnik. Kiev: Knowledge. 2012. 558p. (ukrainian)

[7] G.V. Adzhienko. Development of the concept of water resources Management at the municipal level. Proceedings of the fourth international scientific conference of young scientists and Talented students "Water resources, ecology and hydrological safety". Moscow. 2011. P.9-11. (russian)

[8] GOST R 54612-2011. Passenger cars of locomotive traction and motor-car rolling stock. Requirements for washing and cleaning. Moscow: Publishing house of standards. 2012. 19p. (russian)

[9] V.V. Ilyushina. Modern methods of wastewater treatment. Modern equipment and technologies. 2017. No.2 [Electronic resource]. URL: http://technology.snauka.ru/2017/02/12446 (accessed: 11.09.2020). (russian) 
[10] A.P. Karmanov, I.N. Polina Technology of wastewater treatment [Electronic resource]: textbook: independent educational electronic publication. Syktyvkar forest Institute. Electronic publication. Syktyvkar: SLI. 2015. 201p. (russian)

[11] S.A. Vysotin, A.T. Saifitova, M.V. Khatskov, E.A. Ryazanova. Railway transport as a source of pollution of environmental objects. International student scientific Bulletin. 2017. No.6. URL: http://eduherald.ru/ru/article/view?id=17851 (accessed: 28.09.2020). (russian)

[12] ГOCT 31954-2012. Drinking water. Methods of determination of permanganate oxidation. Moscow: STANDARTINFORM. 2018. (russian)

[13] GOST R 55684-2013. Drinking water. Methods of determination of permanganate oxidation. Moscow: STANDARTINFORM. 2014. (russian)

[14] Yu.Ya. Kharitonov. Analytical chemistry. 2nd edition. Moscow: "Higher school". 2003. 615p. (russian)

[15] SanPiN 2.1.4.1074-01 date of introduction: January 1, 2002 drinking water and water supply of localities. Moscow. 2002. (russian) 